\title{
ЈЕЗИЧКЕ ПРОМЕНЕ ИЗ ПЕРСПЕКТИВЕ ДИЈАХРОНИЈСКЕ СОЦИОЛИНГВИСТИКЕ: ОД ЛАТИНСКОГ ДО РОМАНСКИХ ЈЕЗИКА
}

Сажетак: У овом раду представљам језичке промене из перспективе нове дисциплине, историјске или дијахронијске социолингвистике, која уводи социолингвистичке методе и моделе у дијахронијско изучавање језика. Ова нова перспектива представљена је кроз пример развоја латинског језика, који се након пропасти Римског царства и нестанка његових институција фрагментирао у читаву породицу језика. Посебна пажња посвећена је Иберијском полуострву и језичким варијететима који су се током средњег века на њему издиференцирали.

Кључне речи: језичка промена, дијахронијска социолингвистика, латински језик, романски језици

Језичке промене су неизбежне и неумољиве, упркос жељи прескриптивиста и језичких пуриста свих епоха и меридијана да их зауставе и спрече. Оне су предмет проучавања, пре свега, историјске лингвистике. Традиционална историјска лингвистика, међутим, бавила се увек искључиво резултатима језичких промена, најчешће са велике временске дистанце. Дубљи увид у то зашто до промена долази и како се оне шире у одређеној језичкој заједници омогућила нам је тек социолингвистика, релативно нова дисциплина, настала средином прошлог века, која језичке промене сагледава кроз призму низа друштвених фактора. Социолингвистика се најпре интересовала за језичке промене искључиво из синхронијске перспективе, међутим, последњих неколико деценија њена методологија обогаћена је историјском компонентом, која језичким променама додаје сагледава дијахронијску визуру.

*_akuzmanovic@fil.bg.ac.rs, ana.kuzmanovic@gmail.com 
Ана Н. Кузмановић Јовановић

Ова комбинација језичке, друштвене и историјске анализе представља нову дисциплину коју неки аутори називају истиоријском / gијахронијском сочиолинівисиииком, или яруишвеном историјом језика (cf. Burke, 2004: 2), а која језике посматра у њиховом културном, друштвеном и историјском окружењу.

У овом раду биће представљен модел језичке промене из перспективе поменуте нове дисциплине на примеру развоја једног, латинског језика, у читаву породицу романских језика, уз посебан осврт на социолингвистичку ситуацију на Иберијском полуострву.

\section{1. Увоg: језичке ирромене из иерсиекиииве йрадиционалне и соичолинівистиике}

Језичке промене традиционално су проучаване кроз писана сведочанства из ранијих фаза развоја језика. Лингвистима су на располагању, дакле, били само резултати промене док су њен извор, ток, вертикално и хоризонтално ширење кроз језичку заједницу остајали увек у домену спекулација. Међутим, у последњих пола века, развојом социолингвистике, дијахронијска лингвистика бива обогаћена методама и теоријским моделима ове нове дисциплине. Док се историјска лингвистика бавила интерним, тј. структурним факторима промене, социолингвистика је фокусирана на екстерне факторе промене, оне који су повезани са друштвеним контекстом у најширем смислу. Најпре нам је показала из синхронијске перспективе како се варијантност манифестује у језику а затим је исти модел примењен и на језик у ранијим фазама његовог развоја. Захваљујући социолингвистици данас знамо да је промена инхерентна језику и да се свака језичка промена јавља најпре као једна од многобројних варијанти у језичкој употреби, насталих као последица одређених унутрашњих или спољашњих фактора развоја: закона језичке економије, несавршеног учења језика код деце, језичких контаката или замене језика у двојезичним или вишејезичним заједницама, и др.; међутим, само неке од тих варијанти успевају да тријумфују у делу или целој језичкој заједници, где могу дуже или краће време да се надмећу са старим формама и постепено се, евентуално, генерализују у језику (cf. Kuzmanović, 2006).

Социолингвистика нам је показала и да се сама језичка промена увек реализује кроз одређени друштвени механизам. Захваљујући томе, подложна је синхронијској опсервацији; могу се, на пример, 
ЈЕЗИЧКЕ ПРОМЕНЕ ИЗ ПЕРСПЕКТИВЕ ДИЈАХРОНИЈСКЕ ...

статистички поредити фреквентности употребе одређених ривалских варијанти код различитих старосних група (Pharies, 2006: 14) и тако доћи до одређених сазнања о развоју неке конкретне промене и предикције о њеној генералзацији у језичкој заједници. Еминентни социолингвиста Вилијам Лабов [William Labov] je као основне принципе механизма језичке промене истакао следеће: a) хетерогеност инхерентну језику, б) постепено ширење варијанте кроз језик в) генерализацију језичке промене у систему (Labov, 1963: 273). Подробније испитивање ових фактора показује да су главни узрок језичке промене сами говорници језика и њихове комуникативне потребе (Pharies, 2006: 17), које се непрекидно мењају и пролагођавају новим друштвено-историјским и другим околностима.

\section{2. Исйоријска или дијахронијска варијанйности}

Варијантност је инхерентна језику. Она може бити географска

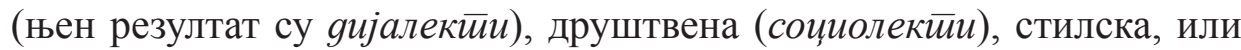
темпорална, односно историјска. Управо је темпорална варијантност предмет изучавања историјске социолингвистике, чији модел језичке промене представљам у овом раду.

Према традиционалном виђењу језичке промене и развоја, у историји сваког језика једна историјска варијанта наслеђује другу варијанту, која јој претходи у времену, према линеарном моделу промене. Такве промене се схематски приказују у историјама језика; на пример, латински LĀTUS [ látus] > хиспано-романски [ládo] >

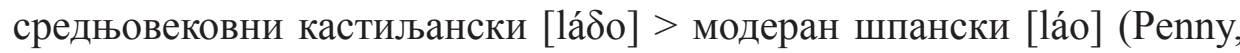
2004: 19). Међутим, данас знамо да промене никада нису овако директне и схематски једноставне. Напротив, различите варијанте у језику могу постојати напоредо дуги низ година, деценија, чак и векова, пре него што дође до смене једног облика другим. Штавише, најновија истраживања показују да у свакој тачки на временској оси један језички елемент у процесу промене увек представља више варијатни које се међусобно надмећу (Penny, 2004: 19). Међутим, језичка промена није ни пука смена старијих новим језичким варијантама, већ у процесу промене постоје и многи ћорсокаци, као и случајеви где старији облици побеђују нове (за детаље и примере вид. Penny, 2004: 21).

Правац и ток дијахронијске варијације никада се не може одвојити од географске и друштвене варијантности. Свака варијанта 
Ана Н. Кузмановић Јовановић

у језику има своју географску и темпоралну путању кроз језичку заједницу, односно језичка промена у неким периодима и на неким територијама напредује брже, а негде спорије; због тога је немогуће успоставити чисто језичке критеријуме за сегментацију и периодизацију историје одређеног језика. Међутим, периодизација је згодан конструкт за политичку или културну историју неког језика и/или народа, на пример, те дијахронијска (историјска) лингвистика свакако покушава да успостави одређену поделу, след епоха у историји језика (на пример, преткласични vs. класични латински; средњовековни vs. савремени шпански; старофранцуски vs. модеран француски итд.), упркос неутемељености таквих подела у стварном механизму језичке промене (вид. Banniard, 2013: 58; Penny, 2004: 22).

2. Моgел језичке ирромене gијахронијске сочиолинївисиике: оg лайинскої ка романским језиичима

Модел језичке промене који нуди дијахронијска социолингвистика може се прикладно представити на примеру историје латинског језика. У питању је језик који се током неколико миленијума историје развио у читаву породицу језика и управо дијахронијска социолингвистика нуди најкомплетније објашњење ове комплексне еволуције.

Бројни су проблеми у успостављању хронологије промене и развоја латинског језика. Пре свега, како разумети транзицију од језичког јединства, оличену у латинском као језику моћног и дуговечног Римског царства, ка језичкој хетерогености и диверзификацији, оличеној у читавој породици језика који су се из латинског развили након пропасти римске државе? У овој еволуцији постоје два посебна, али повезана проблема: прелазак једног језика у други и прелазак једног језика у неколико различитих језика (Banniard, 2013: 57). Традиционална историјска лингвистика није разликовала ова два проблема. У њеном моделу језичке промене, главни узрок промене је екстерни чинилац; наиме, фрагментација латинског била је тумачена као последица "варваризације" и непосредно повезана са историјским околностима пропасти Римског царства, као и успостављањем нових држава на територији некада јединствене римске државе. Важан елемент овог традиционалног модела јесте и постулат о диглосији и постојање паралелног језика, познатог као нарояни или вулїарни лайински (Burke, 2004; Banniard, 2013). У питању је говорни варијетет латинског језика 
ЈЕЗИЧКЕ ПРОМЕНЕ ИЗ ПЕРСПЕКТИВЕ ДИЈАХРОНИЈСКЕ ...

(са различитим географским модалитетима) који стоји насупрот књижевном, писаном латинском језику, тј. варијетету на којем су писана највећа дела римске књижевности, вођена администрација и др. Према овом моделу, који подразумева линеарну, постепену и равномерну језичку промену, оба ова варијетета су се временом мењала: народни латински је еволуирао у модерне романске језике, док се књижевни језик мењао спорије, задржао се као језик администраицје и цркве кроз читав средњи век, прошао кроз неколико реформи (од којих су најважније Клинијевске из 11. века) и коначно "прочишћен" од утицаја народног језика током Ренесансе (тада реформисан и кодификован језик је онај који се и данас изучава).

Међутим, као што ћемо видети, традиционални, линеарни модел језичке промене не представља језичку еволуцију на адекватан начин. Данас, захваљујући модерној социолингвистици, знамо да се језици не мењају по наведеном линеарном моделу, нити се мењају прогресивно и постепено (Banniard, 2013; Penny, 2004; Pharies, 2007), већ су ритам и ток промене увек непосредно повезани са географским, културолошким, друштвеним и другим околностима развоја. Управо нам историјска (дијахронијска) социолингвистика даје дубљи увод у механизме промене који су довели до тога да из једног, латинског језика, развије читава породица модерних романских језика.

\section{1. Развој лаииинскої језика}

Модел језичке промене историјске социолингвистике подразумева примену синхронијских метода на дијахронијско изучавање језика. Синхронијске методе, најкраће речено, обухватају ова три елемента: креирање обимних корпуса (као у традиционалној дијалектологији), анализу уочених образаца и закључке. Међутим, дијахронијски модел мора бити донекле модификован у односу на овај синхронијски. Наиме, није могуће креирати ни довољно обимне нити довољно разноврсне корпусе за дијахронијску анализу будући да су доступни извори ограничени и увек искључиво писани, па је непознанице и рупе у корпусу често неопходно допунити довитљивошћу и маштом истраживача (Kabatek, 2013: 154). Упркос томе, иновативне методе социолингвистике додају нову и важну перспективу историјској лингвистици, дисциплини са дугом и утемељеном традицијом. Као што ћемо видети на примеру развоја латинског језика, у 
Ана Н. Кузмановић Јовановић

том новом моделу језичке промене посебно се истичу три проблема: проблем периодизације, сведочанства и објашњења (Burke, 2004: 8).

\section{1. Периодизаичија}

Постоје различити историјски тренуци (а не само један, тачно одређен) почевши од којих латински постаје мртав језик а романски (romance) почиње да живи. Како бисмо одредили тај тренутак, односно те тренутке, морамо објаснити следеће (cf. Banniard, 2013: 60): шта значи мртав а шта жив језик?; како се латински типолошки разликује од романског, односно романских језика? Треба истаћи да ова метафора о "мртвим" и "живим" језицима" наводи на погрешан закључак, наиме, да језик најпре мора да остари како би умро. Међутим, језици су увек млади уколико их говоре нове генерације говорника; док год постоји трансгенерацијска трансмисија језика, он не може бити мртав. Ова аналогија у потпуности важи и за латински језик. Он никада није престао да добија нове генерације говорника, међутим, временом су се комуникативне потребе његових говорника толико промениле, да се променио не само језик којим су говорили, већ и њихова свест о томе који језик говоре.

Када су говорници постали свесни да говоре језик различит од латинског? Разлике између латинског и романског су, на први поглед, очигледне: латински је претежно синтетички језик, а романски аналитички; латински има СПО ред речи, док је код романског он много слободнији; латински познаје три, а романски само два рода именица; итд. Све ове промене у структури језика биле су постепене и нису довољне да објасне промену свести самих говорника језика ${ }^{1}$. Зато је задатак дијахронијске лингвистике да дефинише критеријуме који ће јој помоћи у реконструкцији хронолошке границе између варијетета; у наставку рада показаћу који су то валидни критеријуми за успостављање ових граница у еволуцији латинског и романског језика.

1 На пример, Законик српског цара Душана писан је на средњовековном срспком језику, који је удаљен од савременог српског као што је латински био од романских варијетета у раном Средњем веку; па ипак, ми тај језик и данас перципирамо као српски, тј. историјски варијетет српског језика. С друге стране, говорници романских варијетета су у једном тренутку (који, као што смо видели, није био јеgaн, тачно одређен) постали свесни да говоре језиком другачијим од оног кодификованог у писаним сведочанствима. 
ЈЕЗИЧКЕ ПРОМЕНЕ ИЗ ПЕРСПЕКТИВЕ ДИЈАХРОНИЈСКЕ ...

\section{3. Свеgочанстива}

Постоје бројни проблеми у вези са подацима добијеним из писаних корпуса, јединих који су доступни историјској социолингвистици. Пре свега, како истиче Banniard (2013: 59-60) аутори тих текстова имали су приступа формалном образовању, те ови подаци припадају другачијој култури него подаци који би били добијени само из усмених извора. С друге стране, разлика између писаног и усменог језика је вештачка и нипошто апсолутна, будући да писани језик увек полази од усменог. Мада је традиционална историјска лингвистика инсистирала на постулату о диглосији на територији Римског царства, разлика између писаног (књижевног) и народног (говорног, вулгарног) латинског није била суштинска, већ стилске природе (Banniard, 2013; Burke, 2004).

Додатни проблем корпуса латинског језика заснованог на писаним сведочанствима јесте тај што је преко 90\% говорника овог језика остало изван домета доступних извора (Banniard, 2013: 63). Овај недостатак ублажава чињеница да огромна већина тих сведочанстава долази из области у којима се данас говори неки романски језик, где je, дакле, романизација била потпуна и трајна, и за које је легитимно претпоставити постојање језичког континуума, налик оном који данас можемо наћи у Латинској Америци, на пример (за детаљну дискусију о овом проблему вид. Banniard, 2013: 63 и даље).

\section{4. Објашњења}

Из позиције савремене теорије, која комбинује методе традиционалне лингвистике и социолингвистике, језичке промене јесу комбинација структурних и друштвених фактора промене. Док су лингвисти у 19. веку језик посматрали као жив организам и говорили о његовом развоју и еволуцији - метафоре које указују на то да су језичке промене и развој одвојене, на неки начин, од самих говорника - данашња, постмодерна лингвистика инсистира на томе да управо говорници мењају језик (Burke 2004: 12-13)². Као што смо видели, ис-

2 Конкретане индивидуалне доприносе језичкој промени ретко можемо регистровати, али добар пример би могли бити неологизми који су захваљујући престижу својих твораца преко књижевног ушли у свакогневни говор - на пример, Шекспир је творац бројних таквих неологизама у енглеском језику (Burke 2004: 14). 
Ана Н. Кузмановић Јовановић

торијска лингвистика инсистира на овој премиси када језичке промене посматра у њиховом ширем друштвеном, историјском и културном контексту.

Када је у питању развој латинског језика током раног Средњег века, традиционално објашњење његовог развоја почива на премисама које су самим говорницима латинског и "раних" романских језика биле стране. Једна од тих премиси јесте диглосија која је владала на територији Римског царства и дихотомија, чак јаз, између писаног, тј. ученог и говорног, тј. народног латинског језика. Први варијетет је, по традиционалном објашњењу, био језик високе културе и администрације, практично неразумљив обичном народу, који је говорио нижим варијететом, тзв народним или вулгарним латинским, из којег су се постепено развили романски језици.

Међутим, ова дихотомија као концепт настала је тек у Хуманизму, у 15. веку (Banniard, 2013: 64.)를 а посебно се раширила у 19. веку, под утицајем позитивизма. У питању је идеолошки конструкт који опстаје до данас, а који је један од елемената традиционалног наратива о пропасти Римског царства и читавог античког света. Тај наратив поразумева следеће елементе: декадентно Римско царство, његов пад, варваризацију и нестанак античке културе коју наслеђује мрачни Средњи век и друге сличне метафоре (о настанку, ширењу и утицају ове дихотомије вид. Varvaro, 2013).

У стварности, на територији читавог Римског царства, чак и након пропасти његовог западног дела, постојао је вертикални континуум стилова и регистара латинског језика. Писани и говорни латински били су повезани, дакле, континуумом варијетета, који је омогућавао опстанак комуникације на овом језику дуги низ векова.

3 Романијом се означава простор на којем се некада говорио латински језик. У питању је територија некадашњег Римског царства, од крајњег запада Европе све до Блиског истока, и од северне Европе до северне Африке. На неким деловима те огромне територије током раног Средњег века развили су се романски језици. Они су касније, у време колонијалног освајања, пренети и у делове света где се латински није никада говорио (Америка, Африка, делови Азије и Океаније); тај се простор некада назива и Новом Романијом. 
ЈЕЗИЧКЕ ПРОМЕНЕ ИЗ ПЕРСПЕКТИВЕ ДИЈАХРОНИЈСКЕ ...

\section{3 Хронолойја иромене:}

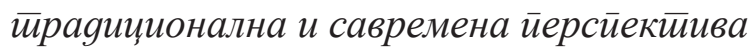

У комуникацији увек постоји информација која се губи; ако је тај губитак превелик, долази до прекида у комуникацији. Ширење тих прекида кроз време и простор указује на језичку промену (Banniard, 2013: 71).

У случају транзиције од латинског ка романском, ове језичке "пукотине" шириле су се захваљујући промени историјско-друштвено-културног контекста до којег је дошло при прелазу из позне Антике у рани Средњи век, односно сменом паганства хришћанством. Падом Западног римског царства нестало је јединство које су одржавале царске институције система, но оно је релативно брзо замењено новим, црквеним јединством (за детаљну дискусију вид. Banniard, 2013). Све су то фактори са важним језичким последицама за некада јединствен језички простор Романије ${ }^{4}$.

\section{1. Пеиии век као іраница?}

Према традиционалној, позитивистичкој историјској лингвистици, 5. век је граница између латинског и романског језика. Међутим, ако упоредимо дело O божјој gржави (De civitatae Dei) Светог Августина, и његове проповеди, текстове који су управо из тог "граничног" века, можемо да закључимо следеће (Banniard, 2013: 67-68): први текст је теолошки, намењен високообразованој елити, док је други намењен простом, необразованом народу (за кога се претпоставља да је у оно време већ говорио романским језиком); међутим, упркос очигледним разликама како у стилу и дискурзивној организацији текста, тако и појединим синтаксичким разликама, у питању је исти језик. Стога можемо претпоставити да је социолингвистичка ситуација у ондашњој говорној заједници латинског језика била иста као и у било ком другом сличном социолингвистичком контексту, како у претходним, тако и у модерној епохи.

4 Романијом се означава простор на којем се некада говорио латински језик. У питању је територија некадашњег Римског царства, од крајњег запада Европе све до Блиског истока, и од северне Европе до северне Африке. На неким деловима те огромне територије током раног Средњег века развили су се романски језици. Они су касније, у време колонијалног освајања, пренети и у делове света где се латински није никада говорио (Америка, Африка, делови Азије и Океаније); тај се простор некада назива и Новом Романијом. 
Ана Н. Кузмановић Јовановић

\section{2. Осийање верииикалне комуникаиије}

Вертикална комуникација (разумевање одређено различитим стилским, а не језичким изборима) на подручју Романије дуги је низ векова била добро очувана. Када је дошло до њеног прекида (што се у различитим деловима некадашњег Римског царства догодило у различитим историјским тренуцима), латински је престао да буде језик који сви разумеју и говоре. Од тренутка када се појавила потреба за новом ортографијом, оном која би могла верније представити нову језичку реалност на територији Романије, можемо говорити о постојању два различита језичка кода, латинском и романском.

Тако, на пример, у визиготском краљевству, на Иберијском полуострву, у 7. веку Сан Исидро, епискор Севиље, помиње два језичка регистра: scholasticus sermo, виши регистар, за ограничену комуникацију и apertus sermo, нижи регистар, за општу комуникцију. Не помиње дихотомију између латинског и романског, јер у том периоду, дакле, још увек постоји језички континуум, мада је већ неопходан напор да се савлада све већа разлика између ова два регистра (cf. Banniard, 2013: 78).

У 8. веку долази до нових промена важних за језички пејзаж некада јединствене Романије. Пропада Меровиншка династија а центар западне цивилизације се помера са Медитерана ка северу Европе, где живе германски народи, већ христијанизовани и у контакту са бројним народним варијететима. На Иберијском полуострву важан је долазак Арапа, пад визиготског краљевства и успостављање нове државе, Ал- Андалуса, у којем је снажан билингвизам између латинског и арапског. Све су то чиниоци који утичу на слабљене језичког континуума латинског језика и продубљивање јаза међу његовим различитим регистрима.

Наредни векови, 9. и 10., јесу период све дубљег дисконтинуитета. По први пут се појављује термин rustica romana lingua, рустични римски језик, односно "латински необразованих људи" (Banniard, 2013: 81), као и потреба да се меровиншки текстови иревоgе на језик Каролинга, иако свест о постојању два различита језичка кода још увек није генерализована међу говорницима. Међутим, комуникативна ситуација зависила је од конкретног географског подручја. Тако се, на пример, на Иберијском полуострву вертикално јединство (између различитих стилова) одржало дуже него у (данашњој) Францус- 
ЈЕЗИЧКЕ ПРОМЕНЕ ИЗ ПЕРСПЕКТИВЕ ДИЈАХРОНИЈСКЕ ...

кој, због посебних напора да се одржи хришћанско јединство у новом контексту исламске доминације.

\section{3. Усйосйављање іраниие између лайинской и романской:} иниеерни крийеријуми

- Фонетски критеријум

Фонетски критеријум за успостављање границе између латинског и романског могао би, на пример, узети у обзир озвучавање безвучних интервокланих фрикатива. Овај феномен се најпре јавља као једна од варијација и постепено се шири кроз различите слојеве римског друштва, све док се није генерализовала. Међутим, поменути процес ширења трајао је вековима и немогуће је одредити када је тачно звучна варијанта тријумфовала над безвучном. Стога је фонетски критеријум недовољно поуздан у одређивању хронолошке границе између два језика.

- Морфосинтаксички критеријум

Ни овај критеријум није довољно поуздан, јер су неке морфосинтектичке конструкције могле вековима коегзистирати у неким дијалектима или регистрима, све док се нису генерализовале. Такав је случај са редом речи у реченици, или колокацијама, на пример.

- Лексички критеријум

У питању је најмање поуздан од свих критеријума, будући да језици непрестано примају позајмљенице из других језика.

- Ортографски критеријум:

Ово је најчешће коришћен критеријум за одређивање границе између латинског и романског. Када је ортографски систем класичног латинског језика постао недовољно прецизан за приказивање нове језичке стварности, било је неопходно створити нови ортографски код за представљање новог језика.

\section{4. Лайински и романски: раздвајање два језичка коgа}

У Француској се, у 9. веку, по први пут појавио нови ортографски систем, ближи говорном језику, а који је постојао напоредо са традиционалним ортографским системом. По први пут су се ова два сис5 Према Wright, 2013: 110-116 
Ана Н. Кузмановић Јовановић

тема могла идентификовати као латински и романски језик (Wright, 2013: 116). Први текст записан новом, романском ортографијом, јесу Заклейве из Сйразбура (лат. Sacramenta Argentariae; фр. Les Serments de Strasbourg) из 842. године. У питању су били текстови који су се изговарали наглас, те отуда потреба да њихова писана форма буде што блискија говорном језику (Wright, 2013: 117).

Нови ортографски системи почели су да се јављају у различитим периодима Средњег века у различитим деловима територије некада јединственог латинског језика. У 12. веку, са каролиншким реформама латинског језика, латински коначно постаје страни језик за говорнике свих друштвених слојева и географских подручја некада јединствене Романије. Вертикална комуникација из претходних векова се губи и два варијетета се све више удаљавају. Међутим, то не значи да је латински престао да се говори, пише или изучава. Напротив; још вековима је уживао виталност у бројним областима друштвеног живота, пре свега у Римокатоличкој цркви, у књижевности, међу адвокатима, званичницима (у бирократији), дипломатама и путницима (Burke, 2004: 44).

\subsection{1. Даља gиверзификаиија}

Убрзо након дефинитивног раздвајања латинског и романског, почињу да се диференцирају различити романски варијетети. Док је дихотомија латински/ романски била заснована на ортографском критеријуму, даља диференцијација романских варијетета заснива се на географском критеријуму ${ }^{6}$.

Почев од 13. века, почињу да се стварају различити ортографски системи за различите регионалне, географске варијетете романског језика. Долазак нове, романске, ортографије у различите делове територија некадашњег Римског царства зависио је, пре свега, од контакта са Каролинзима и домета њихових реформи․

6 Романски представља генерички појам који је обухватао бројне географске варијетете, као на пример, модеран термин карийски шииански.

7 Ови контакти су били најслабији на истоку Европе, територији најудаљенијој од Франачке државе Каролинга. Зато је та територија и језик који се на њој говори одржала континуитет у имену изведеном из Рима - Румунија и румунски језик. Исто тако, заједнице које нису имале потребу да користе латински језик у својим религијским ритуалима, као што су сефардски Јевреји на Иберијском по- 
ЈЕЗИЧКЕ ПРОМЕНЕ ИЗ ПЕРСПЕКТИВЕ ДИЈАХРОНИЈСКЕ ...

Разлози за ову диференцијацију често су били политичке природе. На пример, каталонски се одвојио од окситанског када је краљевина Арагон (која је владала каталонским земљама од раног Средњег века) прекинула политичке и културне односе са Провансом; галисијски се одвојио од португалског када је Португал повратио територије од Мавара и постао независно краљевство; леонски и арагонски нису успели да се у потпуности издиференцирају и конституишу као пуноправни језици, јер су рано потпали под утицај кастиљанског; и тако даље (за детаљну дискусију вид. Wright, 2013). Сва ова периодизација је у великој мери произвољна, јер се најчешће заснива на екстерним критеријумима (као што су одређени историјски догађаји). Те генерализације не умањују значај модела дијхронијске социолингвистике, која нам помаже их контекстуализујемо и добијемо потпунији увид у сам механизам језичких промена које су се одвијале пре много векова.

Треба, такође, истаћи да поменути варијетети током целог Средњег века нису били значајно издиференцирани ри (Wright, 2013: 109) предлажу да се користе веома уско дефинисани географски термини када се говори о њима (на пр. средњовековни наполитански или арагонски варијетет). Важно је, дакле, не посматрати описан историјски контекст из савремене перспективе, јер такво размишљање наводи на формулацију анахронизама и погрешне закључке?

\subsection{2. Романски на Иберијском иолуостирву}

На Иберијском полуострву ситуација је до 12. века била следећа: постојала су три писана језика, арапски (на југу, у Ал-Андалусу), латински (на северу) и хебрејски (на целом полуострву). На хришћанском северу, већина становништва говорила је романски је-

луострву, наставили су да говоре “'латинским" - ladino је назив којим су Сефарди означавали свој вернакулар након протеривања из Шпаније 1492. године (Wright, 2013: 120).

8 Због тога је, између осталог, било могуће у традиционалној хиспанској филологији сматрати Глосе из манастира Сан Миљан и Силос (Glosas Emilianenses/ Silenses) првим текстовима на шпанском, иако потичу из покрајне у којој се говорио не кастиљански (који је, заправо, синоним за шпански језик), већ наваро-арагонски варијетет (вид. Кузмановић Јовановић, 2017).

9 Пример за то су управо поменуте Глосе, проглашене за најстарије текстове на шпанском језику. 
Ана Н. Кузмановић Јовановић

зик који није био представљен ниједном од ових писаних конвенција. За писање је коришћен тзв. "средњовековни" латински језик: њиме су писани краљевски декрети, административна документација, судски записи. Међутим, кад год би било потребно записати нешто што је излазило из оквира овог строгог, формалног регистра, правила латинског би била мање строга а лексика обогаћена свакодневним речима, односно записиван је језик којим се и говорило, тј. романски (вид. Hernández, 2009: 260).

Концепт романскої језика, као нечег другачијег и супротстављеног латинском, јавља се на Иберијском полуострву тек од 11. века, и то најпре у Каталонији, где је утицај каролиншке реформе био најјачи (због географске близине и непосредних веза са Провансом).

У Каталонији се, међутим, све до 13. века користио окситански ортиграфски систем. Чак су и Омилије из манастира Оргања (Homilies d'Organyá), из 12. века, које се сматрају првим текстом на каталонском језику, заправо написане на окситанском, прилагођеном каталонском језику (Wright, 2013: 119).

Традиционално, за прве романске текстове на не-каталонском делу Иберијског полуострва, сматране су тзв. Глосе из манастира Сан Миљан и Силос у данашњој покрајни Риохи (за детаљну расправу о томе зашто ови текстови не могу бити сматрани првим текстовима на шиианском језику вид. Кузмановић Јовановић 2017). Хронологија њиховог настанка је проблематична; најпре су смештене у 10. век, али затим померене један век касније, на 1070. годину. У сваком случају, стручњаци се слажу да крај 11. века (период од 1070-1080) означава почетак дефинитивне појаве романског на Иберијском полуострву (за детаљну дискусију вид. на пр. Alatorre, 2002). То је истовремено и крај раног Средњег века на читавом географском простору на којем се некада говорио латински језик, а на којем се осетио утицај каролиншких реформи. Пресудан утицај на дефинитивно раздвајање латинског и романског имало је увођење литургије на реформисаном латинском (тзв. "средњовековни латински"), које се из Француске пренело на друге делове западне Европе. 
ЈЕЗИЧКЕ ПРОМЕНЕ ИЗ ПЕРСПЕКТИВЕ ДИЈАХРОНИЈСКЕ ...

\section{4. Закључак}

Иако је промена инхерентна језику, њена природа и механизми ширења кроз језичку заједницу дуго су били изван домашаја како лаика, тако и лингвиста, будући да се традиционална историјска лингвистика бавила искључиво резултатима језичке промене. Тек је развој социолингвистике помогао дубљем разумевању овог феномена. Комбинација метода и теоријских оквира истраживања ове две дисциплине - историјске лингвистике и социолингвистике - изнедрила је нови модел језичке промене, модел историјске или дијахронијске социолингвистике, који комбинује структурне са друштвеним, историјским, културним и другим факторима у свеобихватном приступу феномену језичких промена. Поменути модел представљен је у овом раду на примеру развоја латинског у породицу романских језика.

Традиционални модели развоја латинског језика уско су повезани са наративом о успону и паду Римског царства и почивају на концептима који су самим говорницима латинског били страни, будући да се јасна свест о историјском развитку, о успону и паду језика, настаје тек у доба Хуманизма и Ренесансе ${ }^{10}$. Наиме, упркос увреженом ставу о снажној дихотомији између писаног и говорног језика у Римском царству, као и потоњој "варваризацији" која је, наводно, уследила након пропасти западног дела царства, данас захваљујући увидима историјске социолингвистике знамо да је на територији на којој се говорио латински језик постојао не само хоризонтални (географски), већ и вертикални (стилски/ регистарски) континуум, који се одржао вековима након пропасти јединствене римске државе. Различите друштвено-историјске околности довеле су до постепеног слабљења овог континуума, али не постоји јасна нити јединствена хронолошка граница након које латински језик "умире" а рађа се романски. Да би се поставила та хронолошка граница, неопходно је утврдити јасне критеријуме по којима се она одређује. У случају латинског и роман-

10 Италијански хуманиста Лоренцо Вала (Lorenzo Valla) први је повезао успон и пад Римског царства са успоном и падом латинског језика (Burke, 2004: 20). Ову идеју је преузео и Антонио де Небриха (Antonio de Nebrija), аутор прве граматике кастиљанског језика (Gramática castellana из 1492.) који је у посвети краљици Изабели Кастиљанској навео како је "'одувек језик био пратња царству" (Siempre la lengua fue compañera del imperio), те како су латински и грчки некада били оно што је кастиљански сада. 
Ана Н. Кузмановић Јовановић

ског, ортографски критеријум се показао као једини валидан. Када се појавила потреба за верним приказивањем говорног језика, настали су нови ортографски системи. Но, традиционална латинска ортографија није тада нестала, већ су стари и нови систем(и) постојали паралелно и били коришћена за различите комуникативне потребе. Појава новог, алтернативног система на одређеној територије Романије, означава почетак новог, романског језика. Након одвајања латинског и романског, уследила је даља диференцијација романских варијетета, као и њихова потоња стандардизација, а резултат овог хиљадугодишњег развоја је данашња породица романских језика и култура.

Модел језичке промене који нуди дијахронијска социолингвистика најбоље нам помаже да сагледамо сложени сплет интерних и екстерних фактора језичке промене који су условили замену једног језика (латинског) читавом језичком породицом (романском). Ова нова перспектива такође нам помаже да разумемо мањкавости традиционалних модела развоја латинског, махом утемељених на идеологији позитивизма. Будући да је промена инхерентна језику, разумевање њене природе и механизама важан је елемент нашег познавања природе и функционисања самог језика.

\section{РЕФЕРЕНЦЕ}

Alatorre, A. (2002). Los 1001 años de la lengua española. Ciudad de México: Fondo de cultura económica

Banniard, M. (2013). The Transition from Latin to Romance Languages. In In Maiden, M. et al. (eds.). The Cambridge History of Romance Languages, Cambridge: Cambridge University Press, 57-106.

Burke, P. (2004). Languages and Community in Early Modern Europe. Cambridge: Cambridge University Press.

Hernández, F. (2009). The Jews and theOrigins of Romance Scripts in Castile: a New Paradigm. In Corfis, I. A. (ed.). Al-Andalus, Sepharad and Medieval Iberia: Cultural Contact and Diffusion, Boston: Brill, 260-306.

Kabatek, J. (2013). Koinés and scriptae. In Maiden, M. et al. (eds.). The Cambridge History of Romance Languages, Cambridge: Cambridge University Press, 143-186 
Kuzmanović, A. (2006). Sociolinguistics meets historical linguistics: an account of phonological change in Western Romance varieties on the Iberian Peninsula in Filppula, M. et al. (eds). Topics in Dialectal Variation, Joensuu: Joensuu University Press, 45-68

Labov, William (1963). The social motivation of a sound change, Word 19, 273309

Penny, R. (2004). Variación y cambio en español. Madrid: Gredos.

Pharies, D. (2007). Breve historia de la lengua española. Chicago: Chicago University Press.

Varvaro, A. (2013). Latin and the Making of Romance Languages. In Maiden, M. et al. (eds.). The Cambridge History of Romance Languages, Cambridge: Cambridge University Press, 6-56.

Wright, R. (2013). Periodization. In Maiden, M. et al. (eds.). The Cambridge History of Romance Languages, Cambridge: Cambridge University Press, 107-124.

Кузмановић Јовановић, А. (2017). Језичке и научне идеологије у модерној хиспанској филологији: о првим текстовима на шпанском језику. Анали Филолошкої факулиетей, 29 (1), 43-54, DOI: https://doi.org/10.18485/ analiff.2017.29.1.3

\section{Ana N. Kuzmanović Jovanović}

\section{LOS CAMBIOS LINGÜÍSTICOS DESDE LA PERSPECTIVA DE LA SOCIOLINGÜÍSTICA DIACRÓNICA: DE LATÍN A LAS LENGUAS ROMANCES}

Resumen: En este trabajo se presenta el fenómeno del cambio lingüístico desde la perspectiva de una disciplina nueva, la sociolingüística histórica o diacrónica, que introduce los métodos y modelos sociolingüísticos en el análisis diacrónico de la lengua. Esta disciplina nueva se presenta con el ejemplo del desarrollo de la lengua latina que, después de la caída del Imperio Romano y la desaparición de sus instituciones, se fragmentó en una familia lingüística entera. Aparte de un esbozo general de estos cambios, se presta especial atención a la Península Ibérica y a las variedades que se diferenciaron en ese territorio durante la Edad Media.

Palabras clave: cambio lingüístico, sociolingüística diacrónica, latín, lenguas romances 